\title{
Discursive Frictions: the Transitional Justice Paradigm, Land Restitution and Gender in Colombia*
}

\author{
Fricciones discursivas: el paradigma de la \\ justicia transicional, restitución de tierras y \\ género en Colombia
}

Donny Meertens**

Recibido: 13/7/2015

Aprobado: 07/11/2015

Disponible en línea: 30/11/2015

\begin{abstract}
The transition towards a 'post-peace agreements'

state of affairs in Colombia creates special scenarios in which a universal model of Transitional Justice policy -in our case that of land restitution- meets with the local. We should understand the 'local' not only in a material sense -as land and territory-but also as a perspective that brings into circulation different discourses on peasant society, family, gender, justice and development. The following text analyzes the (dis) encounters between different gender discourses and practices, for the purpose of assessing the transformative capacity of the law for gender justice. In this analysis we use the concept of frictions through which we hope to better un-
\end{abstract}

Resumen

En la transición hacia un Estado 'pos-acuerdos de paz' en Colombia, se crean unos escenarios particulares en los cuales el modelo universal de la justicia transicional, implementado a través de la política pública, en este caso la de la restitución de tierras, se encuentra con diversos elementos de lo local. Esto es entendido no solo en su acepción material de tierra y territorio, sino como una perspectiva desde la cual se conjugan discursos sobre la sociedad campesina, la familia, el género, la justicia y el desarrollo. En el siguiente texto analizamos los (des)encuentros entre los diferentes discursos de género, con miras a la capacidad transformadora de la Ley de Víctimas y Restitución de Tierras, en derstand complex interactions, hidden conflicts, materia de justicia de género. Para el análisis se

doi:10.11144/Javeriana.papo20-2.dftj

${ }^{*}$ Artículo tipo reflexión, incorporando resultados de investigación de los Proyectos Memoria Histórica de Despojo de Tierras y Resistencia Campesina en la Costa Caribe (2009-2010); Acceso a la Justicia de Mujeres Indígenas y Campesinas (2011-2014) y Land Restitution and Gender, este ultimo iniciado durante el fellowship en el Woodrow Wilson Center (Washington DC. 2013-2014). * Profesora Asociada de la Facultad de Ciencias Políticas y Relaciones Internacionales, Pontificia Universidad Javeriana. Antropóloga y PhD en Ciencias Sociales. 
ambiguous outcomes, and also new possibilities for agency. emplea el concepto de fricciones, que nos permitirá ver las interacciones complejas, los conflictos ocultos y los resultados ambiguos, pero también las nuevas posibilidades de agencia.

\section{Palabras clave}

Transitional Justice; gender; policy; land justicia transicional; género; política pública; restitution restitución de tierras

\section{Cómo citar este artículo:}

Meertens, D. (2015). Discursive frictions: the transitional justice paradigm, land restitution and gender in Colombia. Papel Político, 2O(2), 353-381. http://dx.doi.org/10.11144/ Javeriana.papo2o-2.dftj 


\section{Introduction}

This article is about the interactions between a public policy of land restitution under the Transitional Justice paradigm, and local discourses that represent other paradigms of social relationships: the gender regime of traditional peasant society; the notions of truth and justice held by victims of conflict; the ideas of productive competitiveness at the core of the rural development model. These interactions 'in the local' shape the outcomes of the public policy in different ways.

In the following we will focus on the interactions that affect the alleged 'transformative capacity' of the land restitution process in terms of gender justice. The idea of gender justice has been best described by Goetz (2007) as a concept -in- construction that became popular in the past two decades among organizations and institutions advocating for women's rights, in reaction to the limitations of the formalistic 'gender equality' (in law) and 'gender equity' (in results) concepts. Gender justice, then, poses a series of questions beyond the normative standards of equity or mere absence of discrimination: how to focus on women's rights (individually and as a structural category) not only vis-à-vis the state, but also -and this is very important-vis-à-vis the family and the community, identified as the locus of gender discrimination? And what should be the role of the state: only minimal, as the guarantor of basic liberties, or interventionist, providing compensation for injustice suffered by women in the past? This brings us to the questions of affirmative actions -deliberate temporary measures promoted by the state for the correction of discrimination that persists in practice (generally in spite of the law) against certain social groups- and accountability as not only corresponding to the state but to the institutions of civil society. Finally, Goetz pleas for a dynamic concept that allows for process and agency to be included (Goetz, 2007; Meertens, 2015, p. 20). These questions, coming from a new and dynamic conceptual field, touch the core of the transitional justice paradigm. This paradigm, internationally accepted as a way of dealing or 'coming to terms' with mass human rights violations in the past, focuses on victim's rights. It is based on a framework of three central elements: truth, justice and reparations, the pursuit of which constitutes the normative horizon for local political decisions (see for its genealogy: Teitel, 2003; Rincón, 2010). The introduction of a gender-lens in this transitional justice model has mainly focused on crimes related to gender-based violence and the role of truth commissions and reparations programs (Rubio, 2009). Only recently, the social and economic dimensions of women's experience during conflict have been taken into account, and with this new analysis, also the recognition of the gender deficits that existed before the conflict have come into the picture, focusing research on "the dynamics of power and control over economic resources; the gender dimensions of the economic system within communities and families; and the cultural factors that determine social and economic status in specific contexts" (Oré, 
2011, pp. 126-127). So the quest for the affectation of women's patrimonial rights during conflict is a relatively new terrain for research, and this is also true for the analysis of restitution of these rights. This has been our rationale for the inquiry into the gendertransformative capacity of the land restitution policy in Colombia.

This inquiry on gender justice in the restitution process goes beyond a traditional policy analysis, as it does not focus on the formulation-implementation-evaluation cycle, but on the discursive practices and encounters that constitute and accompany it. Without abandoning the fields of political science and law -to which the public policy and transitional justice frameworks belong - I will introduce a more anthropological view of public policy in terms of a sociocultural process and connect it with a gender analysis of narratives in both the law and the experiences of peasant women (Ramírez, 2015; Tate, 2015). Moreover, I will seek to encompass some of the terms several researchers, including myself, have used before -like obstacles when talking about women's search for justice, or tensions when analyzing policy models ${ }^{1}$ - into one dynamic concept: that of frictions. I have borrowed this concept from Anna Tsing's famous book on the struggles over an Indonesian rainforest that depict global connections across cultural diversity (Tsing, 2005), following other writers who applied the concept to transitional justice, peace processes and local interactions, deepening my insights on how to use it for the Colombian case (Bjorkdale \& Hoglund, 2013; Hinton, 2011; Shaw \& Waldorff, 2010).

Frictions in Tsing's book refer to the -many times creative and unexpected- effects of (cultural) difference on global interconnections. It represents a way of looking at globalization in terms of frictions instead of "a free and smooth less flow of goods, ideas, money and people" and stresses the importance of multiple interactions for the course and outcome of conflicts between the global and the local (Tsing, 2005, p. 5). Moreover, the notion of agency, as well as two other aspects of this concept make it particularly interesting for our purpose of confronting a universalistic model of Transitional Justice with local realities: (1) it does not stop at the normative human rights framework and formal definitions of justice, but digs into its multiple, subjective, sometimes contradictory meanings and interpretations; and (2) the outcome of the friction may be uncertain and can be compromising or empowering (Hinton, 2011, p. 9); it may paralyze official action or enhance it; it may liberate new energies and empower resistance or trigger a common solution; it may slow down a policy as it becomes entangled in a never-ending process of protracted and cross-cutting conflicts.

\footnotetext{
${ }^{1}$ In the research Project Access to Justice for Indigenous and Peasant Womenin Colombia and Guatemala, carried out by Javeriana University, Antioquia University in Colombia and ECAP in Guatemala 2011-2014.
} 
Frictions may be analyzed between actors, discourses and practices, as Bjorkdahl and Hoglund did in the introduction to a special issue on the uneven encounters between local communities and international peacebuilding efforts. The authors make a distinction between vertical frictions (asymmetrical global-local relationships) and horizontal frictions (between different actors in the local) (Bjorkdale \& Hoglund, 2013). This notion bears similarity to what I have called vertical and horizontal conflicts in the local encounters with the global Transitional Justice model (Meertens, 2015).

However, whereas friction seems to be an adequate term for the analysis of discourses and practices, the concept of conflict (judicial, and sometimes violent) may be more appropriate when these encounters derive into overt or hidden confrontations between actors on the ground. Finally, it is important to make room for a differentiated understanding of not only the local, but also the global (as Tsing indeed does). So, the local may become the scenario of frictions not only between global models and local interpretations, but also between different global discourses, as we will see in the following case study on gender, justice and land.

In this article we will look at the frictions that are produced by the Transitional Justice model of land restitution and the discourses on gender equity in Colombia, following the sequence of its successive administrative and judicial stages. The land restitution policy -part of the Law on Victims and Land Restitution (Law 1448, 2011) is in itself already a 'local' adaptation of the dominant Transitional Justice discourse that circulates among states and international organizations. The Transitional Justice discourse started in Colombia with the Justice and Peace Law in 2005 , under whose umbrella the paramilitary organizations demobilized in a strongly criticized process. Then, following international trends, the attention was shifted from the perpetrators -the (at least officially) demobilized paramilitaries and the still active guerrilla- towards the victims of the conflict, culminating in 2011 with the comprehensive Victim's Law.

This Law is special in two senses: for its comprehensiveness, bringing together humanitarian assistance to the Internally Displaced People and reparations for all victims of conflict-related crimes, including sexual violence; and for its inclusion of land restitution, an in Latin America unique process of restitution of patrimonial rights for those who had lost their land during armed conflict. Again, the implementation of the land restitution process should also be considered a Colombian adaptation of international standards (Hurwitz, Studdard, \& Williams, 2005) to the especially complex circumstances of land dispossession. It has been designed as a combined administrative (to prepare substantial evidence) and judicial (to guarantee a just decision) process; it emphasizes the importance of context for judicial decisions, including detailed ethnographic accounts of violence and the histories of land tenure 
to be established for the claimants ${ }^{2}$; and last but not least it includes a gender (and ethnic) differentiated approach.

This last approach seeks to overcome traditional discrimination of women in access to land rights and 'translates' this preoccupation in a series of affirmative actions for women. These actions are: (1) the prioritization of women heads of household in the restitution process; (2) more flexibility and inversion of the burden of proof for land tenure (which especially benefits women); (3) property titles for all women, be it as autonomous owners or shared with their male partners; and (4) special attention to women's needs and special protection in the post-restitution phase (Law 1448, 2011). Whereas the land restitution process in general is bound to remain within the limits of restoration -not redistribution- of landholdings, the formalization of land titles and the explicit inclusion of women in this process refer to a wish to transform preexisting discriminations. But does it really bring justice to the peasant women? ${ }^{3}$ And what are the prospects for consolidation of these gains in women's patrimonial rights in post-restitution development contexts? This article gives some very preliminary answers to these questions, and analyzes the frictions that arise when the gender sensitive actions of the transitional justice policy interact with other discourses on gender at the local level.

The information for this work-in-progress ${ }^{4}$ has been gathered through field work and desk research -mainly the analysis of judicial sentences on restitution -as well as interviews and information provided by the Land Restitution Unit in Bogotá, over the period 2012-2014. This period of analysis has been complemented with peasant women's narratives on land dispossession and their search for justice in earlier years, gathered and discussed in Historical Memory workshops in the Montes de María region (20092010), and in-depth interviews held for the Access to Justice project (2011-2014) in the Cesar department, both in Colombia's Caribbean coast ${ }^{5}$.

\footnotetext{
2 The restitution process has been under heavy criticism related to these procedures and their political implications. The critiques focus on three problems: insufficient protection for claimants; no clear results in the confrontations with powerful opponents (the so-called 'second occupiers'); and the terrible slowness in its implementation, which may jeopardize the targets for its 10 year validity (Gutiérrez \& Marín, 2014; Revista Semana, 2015, April 20; 2015, April 22).

3 Justice may have many different meanings for peasant women who were forcely displaced and have also been victims of the armed conflict in other aspects of their life (broken livelihoods and life projects; sexual assault; broken families; widowhood). Moreover, Justice may refer not only to property rights, but also to recognition of their productive capacities; and restoration (or enhancement) of their dignity as citizens / rural inhabitants (Ramírez, 2015; Gutiérrez \& Marin,2014). ${ }^{4}$ This and other publications form part of the project: Land Restitution, Transitional Justice and Gender in Colombia, started during a fellowship at the Wilson Center (Woodrow Wilson Center, Washington DC. 2013-2014).

${ }^{5}$ See for research publications: Grupo de Memoria Histórica (2010) and Ramírez (2015).
} 
The purpose of this combination of sources is the construction of a historical timeline for peasant women's experience of violence, dispossession, resistance and restitution in those previous fieldwork sites, which coincide with the micro-regions selected for land restitution. However, information on the post-restitution phase is still very scarce and our preliminary analysis of this phase is based on mostly informal and non-systematic data. Before starting the analysis of land restitution, we will make some short contextual remarks on two topics: the complexities of land dispossession during the last decades of conflict in Colombia and the particular impact of both historical discrimination in land rights and violent conflict on peasant women.

\section{Land 'dispossession' during conflict in Colombia}

Land abandonment and dispossession during the last two or three decades of violent conflict has been estimated by the Monitoring Commission on Government Action and Forced Displacement as more than 6 million hectares (4 million abandonment and 2 million violent dispossession) (Comisión de seguimiento..., 2009). Additionally, the Historical Memory Group (now Centro Nacional de Memoria Histórica) conducted a study on the complex forms of land dispossession and the decline of peasant resistance in the Caribbean coast. The term despojo (which has no clear and unambiguous translation into English) refers to the illegal and mostly violent appropriation of land during armed conflict by private actors -armed and unarmed, legal and illegal. It includes multiple modalities: violent seizure and armed occupation; reversal of former land reform redistributions to the landless; occupation and fraudulent legalization of land titles; forced and below market price selling and buying. In all of these forms, the acts of land dispossession are different from what is known as land grabs in African or Central American countries (Brondo, 2013). Land grabs in those countries are usually part of a process of commoditization of communal lands, promoted by central states in favor of mostly multinational agro-business or extractive companies. One of Colombia's modalities of despojo comes close to this definition, but the phenomenon is more complex; promoted by private actors instead of the state and embedded in the dynamics of territorial governance.

In the Caribbean coastal zone, traditional elites used despojo to hit back to the once successful peasant movement, accusing the communities of parceleros -beneficiaries of land distribution sometimes carried out under the pressure of land occupations by the peasant movement in the past (Grupo de Memoria Histórica, 2010) of collaboration with the guerrilla. As a consequence, a chain of violence was unrolled, which usually started with massacres and the forced displacement of the peasants, mostly committed by the 
paramilitaries ${ }^{6}$, and ended with land abandonment, dispossession and concentration of plots in fewer hands. These sequences led sometimes to the re-establishment of political and economic power by the traditional local elite; other times they created perverse opportunities for the cheap acquisition of land by upcoming national and international entrepreneurs (Centro Nacional de Memoria Histórica, 2014).

On the fringe of these main processes, however, other, less vertical (in terms of power differences) and more messy (Tsing, 2005) engagements have taken place between a range of actors in the shadow of violence Examples of these are the middle peasant who sees the opportunity to enlarge his properties; the parcelero who sells his plot to the extractive industry; the neighbor who buys the land of a widow in order to help her survive; the agro-industrial entrepreneur who deploys local middlemen to buy land from the displaced; the displaced widow who receives land from the warlords seeking to 'repopulate' their strongholds with loyal subjects.... etc. This entangled wilderness of interests, these micro-relations of power and needs, come together in the figure of the so-called 'second occupier' of a piece of land once stolen from a peasant family who fled to the city. The new occupiers usually become opositores (opponents) to the restitution claim made by the original owner, and their arguments must also be heard for the sake of a due process of law. This all makes the land restitution process complex and slow. "It is (legal) protection versus speed" as the former Minister of Agriculture used to say (Restrepo \& Bernal, 2014, p. 35). The conflicts that accompany this 'doing justice' represent one of the most visible and politically sensitive frictions of the process: they generate more violence.

\section{Women's rights to land: historical discrimination and conflict}

Women's access to land and property rights, although legally secured, constitute in practice a long history of exclusion. In Colombia, peasant women have traditionally belonged to the lowest ranks of rural society because of their class and gender position. In practice, land rights for women are not socially acknowledged and therefore, women do not enjoy autonomous rights, as these are always seen as tied to a male head - ofhousehold who acts as the rights-bearer for the family. Moreover, patriarchal bias is also visible in the close association of agricultural and livestock activities with male labor. (Meertens, 2006; Deere \& León, 2000). Furthermore, the cadaster and property registration systems in the rural areas are aged and incomplete, fostering high levels of informal land tenure amongst the peasantry. About $48 \%$ of the country's plots have no

\footnotetext{
${ }^{6}$ In the Caribbean coast, land dispossession and legal appropriation was mostly an act committed by paramilitary, in connivance with local elites and corrupt civil servants. FARC and other guerrilla's frequently displaced peasant communities and used their land for war-related activities, but rarely appropriated it legally and/or economically.
} 
formal title and women are overrepresented amongst the informal tenants (Comisión de seguimiento..., 2009; Restrepo \& Bernal, 2014, p. 132).

Agrarian reform policies have reinforced this male breadwinner-and-rights-bearer model. For many years the peasant family headed by a male 'producer' was the firm basis for rural development and land acquisition. As a consequence, between 1961 and 1999 women constituted only $11 \%$ of land reform beneficiaries (Meertens, 2006). Two well-known researchers on women and land in Latin America, Carmen Diana Deere and Magdalena León, called these the 'familistic' focus of rural policy (Deere \& León 2000, p. 33). This situation changed partially in the nineties when the Agrarian Reform Law (nr. 160 of 1994) created a new category of vulnerable women -female heads of household and forcedly displaced- who could become beneficiaries of land assignments in an associative form. The same Law introduced joint ownership for spouses (also for informal marital relationships), implemented under agrarian reform policy. It has been considered a limited, but progressive step towards gender equality in land rights by providing a legal base for peasant women's bargaining power in the household and in the institutional sphere. However, it also has some limitations. It may hamper women's independent land claims in cases of divorce, abandonment, domestic violence, or disappearance of men in the midst of war; nor does it automatically transform maledominated decision-making on production, credit assignments or inheritance practices. (Deere \& León, 2001, p. 187; Meertens, 2006).

Finally, although the restitution process has not completely abandoned this 'familistic' feature, independent rights for women are now granted individually in case they are female heads of household. This systematic application of land rights-independent or joint - for women in the restitution process has been welcomed by women's organizations as a first step to empowerment in the sphere of rural patrimonial rights.

Dispossession has affected women in particular ways. First, because of their close relationship with the land not only as an economic asset but as a source of livelihood in its broadest sense: work, but also care of animals and crops; belonging, identity - all strongly related to their now disrupted life project. But on the other hand, as women were supposed not to 'know' about production or legal aspects, they many times were kept ignorant about the formal aspects of the finca: its boundaries, monetary value, notarial registration, loans or productive outputs (Grupo de Memoria Histórica, 2010, p. 339) - a lack of knowledge that could hamper the restitution process.

Second, because women, initially, stayed more time in their homesteads than men. On the first threats or massacres, the flow of forced displacement started with the men. This was based on a common imaginary that they were the targets of violence, not women. This idea changed drastically at the end of the nineties, when the paramilitary started to include more women in the massacres, or to target them directly, not as part of a general 
wave of terror, but for specific, gendered reasons: women were killed or sexually violated because they had stayed behind and tried to defend or protect their land; because they did not reveal the hiding place of their husbands; because they were suspect (in case of young women) of 'sleeping with the enemy' (guerrilla or paramilitary) or because of the small services (like making a lunch or running an errand) the adult women delivered as part of the inevitably un-free co-habitation with the guerrilla. Only then, also the women fled and abandoned the land (Grupo de Memoria Histórica, 2010, pp. 340-343).

Third, because widows and women head of households were especially targeted for their vulnerabilities, in many senses: that of sexual violence as a way of pressure to abandon the land (a very well- known case is in the Magdalena department) but also because of their urgent needs for cash in order to survive with their kids, which makes them supposedly more willing to sell the land at any price. However, the women are not always the weakest link in this form of despojo, as the following quote shows. One of the women of an organization called No-Vender ('Not Sell'), in the village of Chengue (municipality of Ovejas) made this statement (Grupo de Memoria Histórica):

One day a man came and told me: you are selling these plots, yes or no?! And I told him NO. First because they are the future for my children; second because I am not going to sell ; you will not be able to buy from the widow [a famous expression for dispossession under threat-DM] because this widow is not going to sell. He offered me a lot of money -12 million pesos per hectare -but I told him: Sir I don’t need money, because this money you are offering does not even fit in my pockets; and the small bit of money I am [currently] earning is enough to eat [...] . [She continues:] The one who still owns his land should not sell and who lost it should recover it, but we should not sell to those people... that's all I have to say. (Peasant woman at the Memory workshop in Cartagena, October 2009) (2010, p. 357)

These particular gendered discourses and practices of exclusion, discrimination and vulnerability (but also of agency), constitute the contexts in which the restitution process evolves and the injustices the policy seeks to redress and to transform. Does it work, and how?

\section{Land restitution: Doing justice to women? The frictions}

We found five main moments of friction in the whole process of restitution: 1) between the Transitional Justice (TJ) model of protection of rights and the gendered aspects of security in the local; 2) between the TJ model of equal access to land, and peasant society's gender regimes and practices; 3) between the TJ model of transformative action and de judges' argumentation; 4) between 'gender' and the idea of justice in the TJ 
model and 'gender' in the development model; and 5) between the individualized rights of the TJ model and collective reparations.

\section{First moment of friction: Equal access}

The first moment for gender analysis in the restitution process is becoming a claimant and filing a claim. The first issue here is that of access: do women file claims? And if so, are they dependent or autonomous claimants? What are the gender-specific obstacles to become a claimant?

Men and women wherever in the country are allowed to file a claim as victims of land dispossession or forced abandonment, and include their spouses in the claim. Two formal limitations have been imposed on this free access for every claimant. The first one is related to the time-span: only claims for land dispossessed after 1991 are taken into account. The second refers to geographical location: only those claims located in the micro-regions (micro focalizaciones) are included in the registry. These micro-regions have been identified for a high density of land dispossession and security cleared by the military. Only in those localities government officials are allowed to start the restitution process. Within these limits, access for men and women claimants is supposed to be free and equal. Even more, the 'gender sensitivity' of the process is reflected in the prioritization of women heads of household for inclusion in the registry (Victims and Land Restitution Law, 2011, Article 115). This can be considered the first intent of a kind of affirmative action provided by the law, in spite of its obvious limitations: prioritization does not refer to structural inequalities but may provide some visibility and relief from extreme vulnerability. However, what happens in practice?

\section{Becoming a claimant: Gendered insecurity and the local}

\footnotetext{
"The entrance to the prosecutor's office was permanently checked by strange men they kept an eye on everyone that entered...so what could I do?"
}

(Indigenous woman in Valledupar, 2012) ${ }^{7}$

The foremost friction with the free- access model of the restitution process is invisible from an implementation point of view, in spite of affirmative measures. Even before the inclusion in the registry, there is the question of becoming a claimant. As the epigraph shows, gender hierarchies tend to create obstacles for women to access the restitution process. Becoming a claimant as a woman-widow requires courage to

\footnotetext{
${ }^{7}$ Interview conducted during the research proyect on "Access to Justice for Indigenous and Peasant Women in Colombia and Guatemala (2012-2014)". Pontificia Universidad Javeriana, Universidad de Antioquia and ECAP (Guatemala), supported by ICRD (Canada).
} 
overcome insecurity in one's immediate environment and to face the moral problems and sense of powerlessness when confronted with family members usurping the land. Although I will analyze these two obstacles separately, both represent gendered forms of insecurity ${ }^{\boldsymbol{s}}$ at the local and at the family level.

Although the initial regions for restitution were selected because of a high concentration of claims and an acceptable level of security ${ }^{9}$ as defined by the Ministry of Defense, this last criteria does not capture the gendered forms of insecurity. These are related to authoritarian and often violent means of social and political control that are still prevalent in many municipalities of the Caribbean coastal zone, particularly in those that were former paramilitary strongholds. Even in the cases where violence decreased after the formal demobilization of the paramilitary, the land restitution process itself challenged the political and economic hegemony of local power holders who had benefitted from violence. Several human rights organizations have reported the increase in insecurity in those regions were restitution claimants organized or peasant organizations re-activated their presence. In 2012 Amnisty International wrote in its first report on the Victims Law:

The Law provides for the protection of vulnerable sectors of society, including those campaigning for land restitution. In recent years Amnesty International has documented and received information on continuing threats against and killings of those campaigning for land restitution and representing displaced communities. Reference to measures to secure protection for these people is positive, but it remains to be seen if these measures will be sufficient and implemented effectively. The approval of the Law has not improved the security situation of those campaigning for land restitution. Amnesty International continues to document such cases and to campaign for decisive action by the government to guarantee the safety of these activists. (Amnisty International, 2012, p. 21)

In many localities, violence related to guerrilla, criminal bands and drug-trafficking continued, and 'anti-restitution armies' have been formed by those trying to uphold their illegally acquired landholdings. As has been stated in the report Far from the Promised Land: "Violence and threats against land rights leaders are intended to

\footnotetext{
${ }^{8}$ Whereas the concept of human security is a first step towards more inclusiveness, because it identifies the person instead of the state as focus for policies, and includes not only 'freedom from fear' but also 'freedom from want' as its more structural goals, the authors of this article argue that the engendering of security brings the perceptions and experiences of women as new areas of concern to the policy table and as such may become a tool for women's empowerment in the transitional and post-conflict scenarios (Hamber et al., 2006, p. 490).

${ }_{9}^{9}$ Assessed by the military and mostly determined by the presence or absence of FARC or ELN guerrilla or BACRIM (the criminal bands related to drugs trafficking and neo-paramilitarism).
} 
accomplish one goal: stop land restitution. They have a powerful impact that goes far beyond the individual leaders and their families, undermining communal efforts to return home and claim promised rights" (Haugaard, Castillo, Tate, \& Romoser, 2013, p. 3). The international organization Human Rights Watch, but also national institutions like the Attorney General's Office and the Ombudsman Office, have reported a high number of killings of land restitution leaders and claimants. The Ombudsman Office found 71 land rights leaders killed between 2006 and 2011, before restitution started. Once the implementation started, the governmental Unit for Land Restitution itself reported over 400 threats against land claimants in 2013 (Human Rights Watch, 2013; URT, 2014).

A significant case is that of the women organized in the Women's Association of Rural Producers (Asociacion de Mujeres Productoras del Campo, ASOMUPROCA) in Pivijay, a municipality in the Magdalena department, also in the Caribbean Coast. They were twice displaced and four of them killed while trying to get their land restituted. Nevertheless some of them filed individual claims for land restitution and a collective claim for comprehensive reparation as a women's organization. But insecurity also divides: an important part of the 75 initial socias did not want to go back to their parcels and desisted from claiming restitution (Amnisty International, 2014, pp. 57-60). Asomuproca is a documented case $^{10}$, but it probably represents the many undocumented cases -those we will never know of- of the women (and men) who out of fear refrained from filing a claim.

Why should insecurity be a 'gendered' obstacle? Of course, also men are targeted by armed local power holders. However, we can make an argument for women being disproportionally victimized in these local contexts, by using two of Margaret Walker's categories of gender (based) violence: gender-skewed violence and gender-normative violence (Walker, 2009, pp. 51-53). Both contribute to withholding women from becoming claimants. The first case is that of general insecurity that affects women in their role as care-givers / survivors who want to guarantee their livelihoods and those of their family, visit local entities, apply for humanitarian assistance or reparations, inquire for their disappeared relatives or claim the restitution of their land. Women are overrepresented in this category precisely because of these traditional roles, and they are especially targeted and threatened because of them.

Perpetrators may still exercise control over women's lives, watching over victims' particularly women's- visits to government, prosecutor's offices, or the local restitution offices (Oficinas Territoriales de Restitución). In the Caribbean coastal provinces, the lower ranks of the paramilitary that were active in the region stayed or returned to their

\footnotetext{
${ }^{10}$ The Victim's Unit, the Land Restitution Unit and the National Historical Memory Center are still working with this group, in order to combine collective reparations for the organization with the restitution of individual plots.
} 
communities. Also, former perpetrators commanders who had demobilized and confessed under the Justice and Peace Law (2005) are now being released from jail, like alias El Tigre who had been active in the Cesar province. The story told by many indigenous and peasant women in Valledupar was that of fear and resignation: they were scared something might happen to their families if they were seen filing a claim. Governmental protection measures in these cases remain inadequate as they rely more on mostly inappropriate mechanical devices or a strategy of temporary organized exile ${ }^{11}$, than on restoring social cohesion or enhancing women's organizations.

Many testimonies of women also refer to re-victimizations by civil servants who do not take their claims seriously or make them even feel guilty of their misfortune (Ramírez, 2015). This is what Walker calls gender-multiplied violence that render women vulnerable to additional harms as a result of the acts of violence (Walker, 2009, p. 52).

The second case, gender-normative violence, is that of the threats and acts of sexual violence, mainly (but not exclusively) directed to the female body. Sexual violence configures a particular risk, but also a never-ending burden for women and their communities, which refrain them from returning to the land, voluntarily, in safety and in dignity ${ }^{12}$. Two examples may highlight this mechanism that prevents the course of justice, including land restitution, after conflict. The first is that of the women in Chivolo, a village in the Magdalena department, a case investigated by the Historical Memory Group (Grupo de Memoria Histórica, 2011). In the Nineties, paramilitary commanders attacked a parcelación - a peasant community of beneficiaries of land reform, as usual accused of being collaborators of the guerrilla. The public rape of one of the women not only forced the displacement of the whole community but also created a double barrier of fear and shame for their return. Only one group of individuals of this displaced, divided and scattered community claimed restitution, which is still in process because of the unsafe local environment. The other example is in the Cesar department. Also in the Nineties, one of the cruelest paramilitary leaders: a. Jorge 40 (now extradited to the USA for drug trafficking) established his headquarters in a rural neighborhood near the capital Valledupar. Peasant and indigenous leaders were murdered and women suffered rape and other forms of sexual violence. All fled the neighborhood, except one brave woman -an example of resilience ${ }^{13}-$. Many of them, especially the victims of

\footnotetext{
${ }^{11}$ Cellphones in localities without connectivity; body guards for women who had been abused by armed men; transfer of mothers of small children to cities in other regions, far away from their families.

12 The three requirements for return of the displaced according to the international Pinheiro Principles OHCHR (2007).

${ }^{13}$ This woman managed to register her land for protection, applied for formalization of the land title and filed a claim for rape by one of the leaders. (Interview July 2009, Access to Justice project).
} 
sexual violence, decided to cross the border to Venezuela and never return (Ramírez, 2015). So sexual violence plays a determinant role for the decisions about return by the affected families and for the damage done to the social fabric of the once cohesive community. Moreover, in both cases, the paramilitary leaders re-populated the rural zones with people they recruited amongst the forcedly displaced (by themselves or by the guerrilla) in the cities, creating this way an (at least initially) loyal rural population that silenced the atrocities committed. These re-populations orchestrated from above by the armed powerholders, generated new conflicts -apparently 'horizontal', that is between equally powerless women- when restitution claims by the first occupants were filed against the second ones, adding even more frictions to the 'justice for all' model.

In conclusion, gender-normative sexual violence, articulated to other forms of violence, is one of the most persuasive and therefore effective weapons for community destruction and constitutes as such a tremendous challenge for the search of justice as represented by a formal claim for land restitution.

The extreme high levels of impunity in all these situations make gender sensitive security an ongoing and in practice unattended problem that creates multiple frictions. These affect decisions to file a claim, to return to the land, to seek compensation or to stay in the cities on the claimant's side; and they may blur the clear limits between 'just' and 'unjust' decisions in the process, on the policy side, as in this last example of horizontal conflict.

\section{Frictions at the micro level: gendered insecurity and family relations}

The land belonged to his [my deceased husband's] father [...] but they didn't give a

plot to our daughters, nor did they give anything to me [the widow].

(Forcedly displaced Indigenous woman, Sierra Nevada de Santa Marta, 2012)

Additional to these two forms of insecurity that refer to the context of violent conflict, another process is at stake, even more silent but also even more effectively undermining women's access to land restitution after conflict. This obstacle to access evolves at the micro-level, pertains to the private sphere, permeates women's daily life, particularly that of widows, but remains invisible for policy measures. It is a form of patriarchal social imaginary and practice as to whom the land belongs: to the men. In the case of widows, and in the context of informal land tenure systems, the land might have been traditionally possessed by the relatives of their deceased or disappeared husbands and returned to them instead, leaving the widow and orphans without compensation. Many peasant and also indigenous women who had widowed and fled to the cities, recalled how they could not return to their land even after violence in the region had calmed down. 
After the assassination or disappearance of their husbands, the in-laws took the land -in their eyes 'legitimately' because it was the man's land- ignoring or denying the widows' and orphans' ownerships rights ${ }^{14}$.

[...]the farm in the mountains was owned by my [murdered] husband [...] and my in-laws sold the property. (Peasant woman in Sucre, 2009).

This history is repeated many times: the land returns to the relatives of the murdered or disappeared man and his widow and children remain without protection. Thus, while these widows, during our interviews, were complaining of the injustices bestowed upon them, they did not file a claim at the Land Restitution Unit. How to denounce and fight your proper family when your region was torn apart by violent conflict? Although only in-laws, they belong to the same peasant community or indigenous pueblo, and the women kept silent in front of formal authorities, not wanting to betray their families and lacking a legitimate argument for defending their cases of unrecognized entitlements.

Finally, family ruptures and re-compositions, as well as unregistered successive and simultaneous marital relationships, also contribute to complexity. Marital relationships frequently break up during displacement and the male partner may now claim the land with a newly constituted family. The originally victimized family members, although also rights bearers, are not always aware of these claims and left without recourse. We can only guess how many abandoned women were not aware of their rights as victims of displacement and land grabbing, or how many are aware but do not want to risk their arduously re-built livelihoods in the city for a fight in court with her former husband. Sometimes we catch a glimpse of these hypothetical cases when reading the restitutionjudges' arguments for doing 'right' in complex family situations.

\section{Starting the process of inclusion: Prioritization of women heads of household}

During the law's first two years of implementation over 54.000 victims filed claims, $39 \%$ (15.523) of them women. More than half of them (8.675) presented the claim together with a spouse, and a slightly smaller group (6.848-44\%) did this alone, 4370 of them widows (Unidad de Restitución de Tierras, 2013; Unidad de Restitución de Tierras, 2014). In each case, a time-consuming study has to be made in order to determine a woman's status as head of household and former inhabitant of a micro-focalized region, and establish thus her eligibility for prioritized inclusion in the registry. So, the affirmative measure of prioritization, meant to accelerate, in practice has become a very slow process,

\footnotetext{
${ }^{14}$ The formal legal system confers equal heritance rights to men and women, and to female and male offspring (Deere \& León, 2000).
} 
as numbers show for September 2013: whereas 44\% of the female claimants presented their case alone, only $6 \%$ of the same group (1058 cases at that moment) received a socalled Acto de Prelación (priorization act) ${ }^{15}$.

As we will see further on, the participation of women shows a downward trend when we move on through the restitution process. At the end of 2013, about 900 court rulings for restitution had been issued (less than $2 \%$ of the claims). In our sample of 33 Court Rulings (160 cases) on restitution in the Caribbean coastal region (departamentos Cesar, Bolívar and Sucre), we found that most of them involved women as partners or dependents and only a third part (29\%) acted in their own right -much lesser than the $39 \%$ of initial claimants. It seems, thus, that in the case of women claimants the outcome of the judicial process itself is more time-consuming and complex. Friction with the bureaucratic requirements slows down the process of prioritization, hopefully generating more protection of rights.

\section{Second moment of Frictions: Between good practice and traditional argument}

[...] la propiedad de la tierra es una relación social, una praxis de acceso, conservación y mejora que, en el caso de la propiedad campesina, primero se legitima en el tejido de los vecindarios y solo después, eventualmente, en las instituciones del Estado.

(Palacios, 2011, p. 71)

The text of the Law takes at heart this statement by a historian writing about peasant society in the 1930s: the preparation of the judicial case starts with an ample review of the social relationships, land tenure and community life in the locality where the despojo took place.

Preparing the case for the judge contains several actions that may result favorable for women victims as they used to be the less documented or knowledgeable party on land questions. Article 114 of the Law refers to a special window for women; gender training for personnel, measures to promote women's organizations' access to reparation; facilities for children, amongst others (Victims and Land Restitution Law, 2011, p. 66). But not so much the 'special windows' or childcare facilities, mentioned in the Law, as well the detailed ethnography of conflict and the social mapping, help to contextualize violence and sensitize judges on the position of women in the family and the community - or at least is supposed to do so. A second element in this stage is the extensive and systematic

${ }^{15}$ Information provided by URT in its answer to a formal petition for information filed by the author. An inconsistency ocurred as the total number of women claimants reported in the different documents varied between 15.523 and 17. 736. However, the general pattern is what matters here. 
use of testimonies as elements of proof -for land tenure, victim status, marital status and family life- that make the whole process more flexible (although not completely different) compared to ordinary justice procedures. This is complemented with a series of legal presumptions (Article 77, p. 51) about the lack of consent in case of land sales or irregular land transfers during violence, making them invalid, and the reversal of the burden of proof towards the opponent (Article 78, p.51).

Testimonies are complemented with social mapping and time-lines, research techniques common in historical memory work to define sequences of violence, displacement and land usurpation. It is striking that certain gendered forms of victimization are not mentioned ${ }^{16}$, particularly the silence about sexual violence, but the gendered forms of landownership (autonomous, or dependent of a spouse; or formal /informal) are usually recorded.

The judge has to validate this information and contrast the claims and counterclaims. For the first time (in rural policy history) he (or she, many female judges are employed) will give land deeds to individual peasant women, autonomously when she is a widow or head of household, or shared in case a spouse or partner is present. As Article 118 reads:

In all the cases in which the claimant and his wife or husband or permanent partner have been victims of forced abandonment of their land or dispossession of the real estate that is claimed, the judge or magistrate should order the restitution or compensation to both of them, and also [...] order the Real Estate Registry Office to put the property to the names of both, even when the wife, husband or partner did not present him or herself to the Court. (Victims and Land Restitution Law, 2011, pp. 66-67)

The practical result is positive for those women, victims of conflict, who managed to become restitution claimants and navigated positively through the process. But does it mean a new discourse in general on women's access to land and property rights? The analysis of the judicial argumentation might give us a clue of the vision of judges on gender relations in peasant society.

The legal relationship of this woman with the land can be proven through her relationship with the late Mr. X, as she was his permanent partner. Mr. X occupied this plot of state land since 1957. (Court Ruling (Sentencia) oo3, October 22 2013, San Juan de Nepomuceno, Bolívar)

During our analysis of the 33 court rulings (160 cases), we found, over and over again, the same argument, the same patterns of reasoning by the judges: the proof of land

${ }^{16}$ I only found one, generic, reference to threats of sexual violence in the examined Court Rulings (as 'existing in the locality', not in relation to dispossession). 
tenure for a woman claimant still is her relationship with a man, in the present or in the past. This man may be absent, or dead, or disappeared, but their former relationship plays a crucial role and should be established through testimonies or extra - judicial declarations of family or community members. Or through the documentation filed by the Colombian land reform and rural development institute INCODER. (As we have seen in Chapter 3, many -and perhaps most- of the cases of violent land dispossession in the Caribbean coast were perpetrated against the clusters of peasant lands that had resulted from the divisions of former haciendas. The INCODER filed the application forms for land assignment and the -always male- applicants had to report their family members and spouses, like in the following case quoted by the restitution judge:

In an extra [...] it has been stated that $\mathrm{mr}$. H. and mrs. E. lived together in marital union for 30 years [...]. Moreover, a registration form has been found for land assignment completed by mr. H and including mrs. E as his partner [compañera]. (Court Ruling (Sentencia) 0143, August 27 2012, San Diego, Cesar)

In conclusion, although the practice has changed in the restitution process -an autonomous land deed is given to a woman claimant who is head of household, or an adult heir, the discourse has not- being the judicial argument still embedded in a traditional, patriarchal vision of gender relations in peasant society.

One might argue that no alternatives are available for this kind of judicial procedure. However, we only need to look at the Colombian agrarian legislation to find a very common procedure, mostly applied to men, for establishing property rights of state lands (baldíos), based on a minimum of 5 years continuous exploitation of the plot (Law 160 art. 72, 194). So why should the exploitation of the land not be a criteria for women? In the court rulings we have analyzed, the judges never asked for a woman claimant's role in the exploitation of the land, or in the productive and reproductive tasks -so interwoven in a peasant household - they had performed. But we found an exception, a very significant one. A man, who had abandoned the locality and declined his land rights, left two parallel families behind, a very common figure in the Caribbean region. Both women claimed the land for themselves and their children, one as claimant the other as opponent. The judge resorted to the most logical argument: he restituted the land to the woman who had lived, worked and exploited the plot for years (italics mine) ${ }^{17}$ :

\footnotetext{
${ }^{17}$ Whereas the other woman got inheritance rights also for her children. These cases require more study from a family and inheritance law point of view.
} 
A year after she left the plot [displaced by violence], the claimant decided to come back to the village and so she returned to the land and continued to work on it and carry out its exploitation for her economic survival. (Collective Court Ruling 0029, 2013, Colosó, Sucre)

This example shows us how only at the moment the relationship with a man does not resolve the property rights for women, the exploitation of the land becomes a valid means of proving her land tenure in the past. In the transitional justice practice this is still considered an exceptional case for establishing land rights for women, whereas in the normal agrarian legislation it is a common figure for (mostly) male claimants of waste lands.

The recurrent reasoning in terms of property rights for women vía her marital relationships does not affect directly the positive outcomes for women becoming title holders in the course of the restitution process. Nevertheless, the way the rulings are phrased show how the traditional discourse on male-mediated land rights has been kept in place. We may ask, first, how a new mechanism for establishing women's land rights through land 'exploitation' or 'work' (including domestic work!) might become a transitional justice tool and, ultimately, be incorporated in 'normal' civil (family, agrarian) law. And second, what effect the still prevailing patriarchal discourse might have for the peasant women in post-restitution times, on their recognition and self-recognition as new property holders and as active citizens in the productive and social rebuilding of their communities.

\section{Third moment of frictions: Where does 'transition' end? Post-restitution, gender and development}

The Victim's Law provides two articles with special considerations for women's security during the handing-over of the land and for improving the conditions for women's livelihoods after restitution. Protection measures are cautiously formulated: for accompaniment by the police, women's consent is required on beforehand - a condition pressed by the women's organizations and based on the traumatic experiences of women victims with armed men in their environment.

Article 116. Handing over of the land. Once the judge orders the handing over of the land to a dispossessed woman, the Land Restitution Unit and the Police and Military authorities should collaborate in order to safeguard the handing over and look after the maintenance of security conditions that allow the usufruct of the property, under the condition that previous consent has been provided by the women victims and the adoption and implementation of these measures has been fully agreed upon. (Victims and Land Restitution Law, 2011, p.66)

The other benefits are taken from the old, under-enforced (Ni Aolaín \& Rooney, 2007; Law 731 on Rural Women, 2002). Sometimes the judges add a recommendation 
for implementing the measures in a gender-sensitive way, without any specifications of what that might be; the article in the law only refers -again- to prioritization:

Article 117. Priority for the application of benefits under the Law 731 (2002) with respect to loans, land adjudication, warranties, social security, education, training, recreation, family subsidies, reforestation and provision of identity documents. (Victims and Land Restitution Law, 2011, p. 66)

This post-restitution phase represents a cross roads for both the institutional process, and for the daily lives of the women victims themselves. The Court rulings mark the end of an era: justice has been done, at least in the formal terms of law. For the follow-up, we may use again the metaphor of the funnel: the broad analysis of context, communities, social organizations and processes in the local have nourished the argumentation and final decision taken by the judge. But once the sentence has been delivered, those social processes are no longer taken into account: a series of individual local measures are ordered by the judge for protection and special benefits for women. Formally, the judge maintains control over the implementation of his orders, but in practice no effective follow-up mechanism has been established. Instead, a whole array of local, national and decentralized, institutions are involved in the execution of the judges' orders after handing over the land. And although the Victims Unit (the other institution for Victims depending directly of the Presidency) is formerly in charge of overseeing this process, no information on what happens to the "restituted" men and women is available. Lack of transparency and lack of institutional coordination is already a commonly heard criticism.

What happens after the Court ruling, that is, the judicial restitution? No information is available on the progress made in material restitution (the handing-over of the land); and no data are available on the return of de restituted women to the countryside. We might gain some preliminary insights through case studies.

Three options are available for the restituted: first, they accept the judicial restitution but do not do so with the handing over of the land because they don't want to return for a set of reasons. These may be worries about local security, but also about the prospects for empowerment or leadership for women. As one woman in Bogotá, displaced from Meta, stated: "I don't want to go back and submit to militarist attitudes". And another added: "I don't want to go back to those situations where they undervalue my labor" (Garcés, 2014). Second, they accept de handing over of the land, but leave it unexploited. (Garcés, 2014). These women (in both cases) may wait for the required two years to pass and then sell the land. Third, the 'restituted' women may return and apply for a production plan. Also in this phase, a gender approach for production plans and credits should be implemented, according to the Law's indications (URT, 2014). In the case 
studies of restituted families in the municipalities of San Carlos and Granada (department of Antioquia), women's agricultural labor and commercial activities have become more important for the family economy, but are still not fully recognized (Torrejón, Posada, \& Castaño, 2015).

Definitely, the post-restitution phase is an important indicator for the degree of success of the restitution process and therefore its data are so politically sensitive. One way of avoiding negative judgment on the Law's implementation results (by both public opinion and political -congressional- control) is focusing on the judicial sentences, not on the material follow-up. However, for any discussion of gender-sensitive post-conflict public policy, the monitoring of post-restitution measures and the way they will be linked to development policy are crucial. And we find several important frictions.

The first friction lies in the logical articulation of the gender approach in restitution, with the gender approach in the Formalization of Tenure Program (Law 1561). This program employs the same standards: women are always included in land titling, autonomous when she is head of household and shared when she lives with a partner. However, the Formalization Program avoids explicitly the conflict and restitution zones, so there is no territorial connection between the two programs. This could make sense in the long run, but for the transitional moment it is a bad idea: it generates frictions because of territorial discontinuities in terms of women's empowerment and overarching organizational opportunities, including both victims (restituted women) and non-victims (peasant women in the same region).

The second friction is even more important. It refers to the linking of the gender equity concept in the restitution process, that is, based on some form of (transitional) justice for women / victims, to the gender equity concept practiced in rural development policy, that is, based on a totally different concept: that of equality for women as economic subjects, as agro-industrial producers capable of competing with men and men-led companies. The frictional encounters become manifest in the way productive projects for women are handled and financed. Initially, the land reform institute INCODER and the Agrarian Bank (Banco Agrario) accepted to help finance production for restituted women. But not unconditionally: they should raise part of the money by themselves.

As this was not viable for the displaced women who, returning to the countryside without resources would have immediately been excluded from finance, the government decided to fund productive projects through its Restitution Unit. That is extending the transitional justice scheme for another two years (the period of productive consolidation planned in the policy). So the friction generated a new solution-but for how long? It brings us also to the question of where should Transitional Justice end? 
How could reparations and restitutions link to, or transform the development policies and institutions for 'normal' times? (Rincón, 2010) ${ }^{18}$. For the moment, the program for Rural Women of the Ministry of Agriculture collapsed as a result of its double failure: to make women into 'viable' economic subjects and to do that from a (transitional and social) justice perspective ${ }^{19}$. Friction, in this case, paralyzed, or at least suspended, official action under the 'gender and development model' (until its re-design should be more in accordance with 'justice'?).

The fourth moment of frictions: 'Restituted' peasant women: the end of collective victimhood? Land, identity and citizenship

The post-restitution phase, as we saw, is a crossroad. It represents the end of an era, not only for government action, but for a political subject that came to life in 1997, in the heat of armed conflict, with the official acceptance of the term forcedly displaced people and afterwards the recognition of special vulnerabilities -and agency- of displaced women. Many years later the victim's discourse - represented overwhelmingly by women- overshadowed the humanitarian category of the displaced. The recognition of gender-based and particularly sexual violence represented an important step forward for a gender-differentiated approach to the impacts of violent conflict, but posed a serious problem for agency.

The claim for truth and justice in cases of sexual violence can be a base for collective legal or symbolic action (mostly by women's organizations) but meets with serious inhibitions as a personal vindication in the context of displacement, return or restitution. More in general, being a victim becomes an important framing for individual and collective claims (for assistance, reparations or restitution). In spite of being a transitory category in theory, victimhood acquires an element of identity, both in the process of labelling by bureaucratic entities, as well as in the struggles for recognition by social organizations vis á vis the state (Malkki, 1992; Meertens, 2013; Waardt, 2014). Post-restitution (at least in theory) puts a sudden end to two constitutive elements of victimhood: displacement and land dispossession. This doesn't mean all forms of victimization have ended, but it puts an end to their use as the dominant identity marker in the new social, political and economic context.

The building of 'post restitution identities' becomes urgent. Is the 'new peasant woman' arising as a collective subject? We have identified three important interrelated frictions in the way peasant women, individually and collectively, interact with the postrestitution phase. The first one is that between the completely individualized restitution process (we already commented upon this feature) and the first attempts of collective reparations by former peasant women's organizations, like the national ANMUCIC or

\footnotetext{
${ }^{18}$ This question, put here in gender terms, also refers, of course, to the more general question of the interaction between 'justice' (not only transitional but social) and the current development models. ${ }^{19}$ See for severe critique on the Program Mujer Rural (Vargas \& Villarreal, 2014).
} 
the regional organization ASOMUPROCA. According to the Victims law, on the one hand, collective reparations cannot include land, and on the other, land restitution can only be an individual process ${ }^{20}$, with an exception for the ethnic -based communities (indigenous and afro-colombian) who inhabit collectively owned territories. The second one is that those peasant women's organizations that existed before violent conflict, are looking to the past: and formulating claims in terms of reparations for the harms and losses they suffered as organization during violence. This looking to the past focusses on the impact of violence on their organization as a political subject in the first place. So support for a meeting place is their first claim, not the land.

The third friction is that of the limitations of collective subjects to be repaired as defined in the law. Many displaced women who suffered individually the impacts of violence, organized as displaced women in the city, and now prepare a collective return to the countryside. But they do not qualify for collective reparations, nor for collective ownership of the land, because they organized after suffering the consequences of violent conflict. In conclusion, these frictions hamper seriously the search for new collective identity as peasant women, linked to the newly acquired landownership; on the other hand generate new energy for women to deal with the past and become political subjects. More action is needed to make them also true citizens in representation of the rural areas.

\section{Conclusions: a preliminary balance}

The 'transformative capacity' of the restitution process in terms of gender justice is not only limited by the outcomes of the Havana talks and the uncertainties of a postconflict scenario. It also moves back- and forward through a series of frictions with other gender discourses: those that circulate in peasant society; in judicial and development institutions, women's organizations and even in the historical memory work that is part of the same Transitional Justice framework.

The advantage of the 'frictions' concept is its versatility for the analysis of process and agency in the multiple interpretations of gender justice, without pointing, on beforehand, to a negative outcome. These frictions show us that women becoming landowners is potentially a positive process, but the act of individual titling is not enough. It should be 'owned' collectively and symbolically for its consolidation, that is, by territorially based peasant-women's organizations. For this to happen, collective reparations constitute a good starting point. Although primarily focused on the past, these processes might help create a new collective identity for women-victims who return to the countryside.

\footnotetext{
${ }^{20}$ In theory, the Law provides the modality of 'accumulation of cases' (neighbors in the same territory, same violence, same forms of dispossession) but even in these processes the judicial form finally requires case by case procedures. Restrepo and Bernal on this topic (2014, p. 35); Restitution of Ethnic collective lands is regulated by special decrees.
} 
There, they should start the confrontation with judicial institutions', civil servants', development workers', husband's and male family members' imaginary on women and land. And continue the transformation of gender relations in rural society.

\section{References}

Amnisty International (2012). Colombia: the Victims and Land Restitution Law. An Amnisty International Analysis. London: Amnisty International.

Amnisty International (2014). A Land Title is not enough. Ensuring sustainable land restitution in Colombia. London: Amnisty International.

Bjorkdale, A., \& Hoglund, K. (2013) Precarious peacebuilding: friction in global-local encounters. Peacebuilding, 1(3), 289-299. http://dx.doi.org/10.1080/2164725 9.2013.813170.

Brondo, K. V. (2013). Land Grab. Green Neoliberalism, Gender, and Garífuna Resistance in Honduras Tucson: University of Arizona Press.

Buckley-Zistel, S., \& Zolkos, M. (2012). Introduction: Gender in Transitional Justice. En Buckley-Zistel, S., \& Stanley, R. (Eds.). Gender in Transitional Justice (pp. 1-33). Houndmills (UK) and New York (USA): Palgrave MacMillan.

Centro Nacional de Memoria Histórica (2014). La Tierra en Disputa. Memorias del despojo y resistencias campesinas en la Costa Caribe (1960-2010) Resumen. Bogotá: Centro Nacional de Memoria Histórica

Céspedes, L., Peña, R., Cabana, D. S., \& Zuleta, S. (2015, june). Who Owns the Land? Litigants, Justices, Colonos, and Titleholders' Struggle to Define the Origins of Private Property in Colombia. Global Jurist. http://dx.doi.org/10.1515/gj-2014-0029.

Comisión de Seguimiento a la Política Pública de Desplazamiento (2009). El reto ante la tragedia humanitaria del desplazamiento forzado Vol. 5: Reparar de manera integral el despojo de tierras y bienes. Bogotá: CODHES.

Congreso de la República de Colombia (1994, August 5). Ley 160 de 1994 (Agosto 3) Por la cual se crea el Sistema Nacional de Reforma Agraria y Desarrollo Rural Campesino, se establece un subsidio para la adquisición de tierras, se reforma el Instituto Colombiano de la Reforma Agraria y se dictan otras disposiciones. Diario Oficial, (41.479).

Congreso de la República de Colombia (2002, January 16). Ley 731 de 2002 (enero 14) Por la cual se dictan normas para favorecer a las mujeres rurales. Diario Oficial, (44.678). 
Congreso de la República de Colombia (2011, June 10). Ley 1448 Por la cual se dictan medidas de atención, asistencia y reparación integral a las víctimas del conflicto armado interno y se dictan otras disposiciones. Diario Oficial, (48.096).

Deere, C. D., \& Leon, M. (2000): Género, Propiedad y Empoderamiento: Tierra, Estado y Mercado en America Latina. Bogotá: Tercer Mundo Editores.

Deere, C. D., \& Leon, M. (2001). Empowering Women. Land and Property Rights in Latin America. Pittsburg: University of Pittsburg Press.

Fraser, N. (2009). Scales of Justice. Reimagining Political Space in a Globalizing World. New York: Columbia University Press.

Garcés, D. (2014). El proceso de restitución de tierras para mujeres rurales. La transformación de la división sexual del trabajo en la trayectoria de vida de las mujeres rurales reclamantes; caso de puerto Gaitán, Meta. Work in progress, thesis chapter, Bogotá: Universidad Nacional, Escuela de Estudios de Género.

Goetz, A. M. (2007). Gender Justice, Citizenship and Entitlements: Core Concepts, Central Debates and New Directions for Research. En Mukhopadhyay, M., \& Singh. N. (Eds.). Gender Justice, Citizenship and Development (p. 15). New Delhi: Zubaan / Ottawa: IDRC.

Grupo de Memoria Histórica. (2010). La Tierra en Disputa.Memorias del despojo y resistencias campesinas en la Costa Caribe (1960-2010) Bogotá: Fundación Semana y Taurus.

Grupo de Memoria Histórica (2011) Mujeres y Guerra. Víctimas y Resistentes en el Caribe Colombiano. Bogotá: Fundación Semana y Taurus.

Gutiérrez, F., \& Marín, M. (2014). Los colombianos y los problemas agrarios: encuesta de opinión sobre los problemas agrarios. Colombia, Segundo Reporte 2014. Bogotá: Observatorio de Restitución y Regulación de Derechos de Propiedad Agraria. Retrieved from http://www.observatoriodetierras.org/wp-content/ uploads/2014/o1/informe-encuesta-17122014DEFDEF-LERG-1.pdf

Hamber, B., Hilliyard, P., Maguire, A., McWilliams, M., Robinson, G., Russell, D., ... Ward, M. (2006). Discourses in Transition: Re-Imagining Women's Security. International Relations, 2O(4), 487-502.

Haugaard, L., Castillo, Z., Tate, W., \& Romoser, A. (2013). Far from the Promised Land: Land Restitution on Colombia's Caribbean Coast. Washington DC. : Latin America Working Group Education Fund and Baltimore: Lutheran World Relief.

Hinton, A. L. (2011). Transitional Justice: Global Mechanisms and Local Realities After Genocide and Mass Violence. New Brunswick: Rutgers University Press. 
Human Rights Watch (2013, September 17). The Risk of Returning Home. Violence and Threats against Displaced People Reclaiming Land in Colombia. Retrieved from https://www.hrw.org/report/2013/o9/17/risk-returning-home/ violence-and-threats-against-displaced-people-reclaiming-land

Hurwitz, A., Studdard, K., \& Williams, R. (2005). Housing, Land, Property and Conflict Management: Identifying Policy Options for Rule of Law Programming. Policy paper. International Peace Academy. Rome: FAO.

Malkki, L. (1992). National Geographic: The Rooting of Peoples and the Territorialization of National Identity among Scholars and Refugees. Cultural Anthropology, 7(1), 24-44.

Meertens, D. (2006). Tierra, derechos y género. Leyes, políticas y prácticas en contextos de guerra y paz. Bogotá: UNIFEM.

Meertens,D. (2013, April). Transforming Gender Inequalities in Land Restitution: what are the Issues? Notes for a Peace Agenda. Washington, USA: United States Institute for Peace. Retrieved from http://www.usip.org/events/ colombia-land-and-the-agenda-peace.

Meertens, D. (2015). Conflictos ocultos en la restitución de tierras. Una mirada de género a la justicia transicional 'en acción'. En Churruca, C. (Ed.). Colombia: ¿Cómo construir la Paz? (pp. 177-200). Madrid: La Catarata.

Merry, S. E. (2010). Derechos humanos y violencia de género. El derecho internacional en el mundo de la justicia local. Bogotá: Siglo del Hombre Editores and Universidad de los Andes.

Ní Aoláin, F., \& Rooney, E. (2007). Underenforcement and Intersectionality: Gendered Aspects of Transition for Women. The International Journal of Transitional Justice, 1, 338-354. http://dx.doi.org/10.1093/ijtj/ijmo31.

Oré, G. (2011). Asserting Women’s Economic and Social Rights in Transitions. In Oré, G. \& Gómez, F. (Eds.). Rethinking Transitions. Equality and Social Justice in Societies Emerging from Conflict (pp. 123-170). Cambridge, Antwerp, Portland: Intersentia.

Office of the High Commissioner for Human Rights (OHCHR) (2007). Handbook on Housing and Property Restitution for Refugees and Displaced Persons Implementing the 'Pinheiro Principles'. Retreived from: http://www.ohchr.org/ Documents/Publications/pinheiro_principles.pdf

Palacios, M. (2011). ¿De quién es la tierra? Propiedad, politización y protesta campesina en la década de 1930. Bogotá: Fondo de Cultura Económica and Universidad de los Andes. 
Ramírez, P. (Ed.) (2015). El camino por la justicia. Victimizaciones y resistencias de mujeres indígenas y campesinas en Guatemala y Colombia, Medellín: Universidad de Antioquia.

Restrepo, J. C., \& Bernal, A. (2014). La cuestión agraria. Tierra y posconflicto en Colombia. Bogotá: Penguin Random House.

Revista Semana (2015, April 20). Benedetti denuncia rezago con la restitución de tierras. Revista Semana. Retrieved from http://www.semana.com/nacion/articulo/ armando-benedetti-denuncia-rezago-con-la-restitucion-de-tierras/424840-3

Revista Semana (2015, April 22). Los resultados de la restitución de tierras son históricos. Revista Semana. Retrieved from http://www.semana.com/nacion/articulo/ ricardo-sabogal-urrego-los-resultados-de-la-restitucion-de-tierras-en-colombia-son-historicos/425057-3

Rincón, T. (2010). Verdad, Justicia y Reparación . Lajusticia de la justicia transicional. Bogotá: Universidad del Rosario.

Rubio, R. (2009). Gender and Collective Reparations in the Aftermath of Conflict and Political Repression. In Rubio, R. (Ed.). The Gender of Reparations. Unsettling Sexual Hierarchies While Redressing Human Rights Violations (pp. 381-402). Cambridge: Cambridge University Press,

Shaw, R., \& Waldorf, L. (2010). Introduction. In Shaw, R., \& Waldorf, L. (Eds.). Localizing Transitional Justice. Interventions and priorities after mass violence (pp.3-26). Stanford (CA): Stanford University Press.

Tate, W. (2015). Drugs, Thugs, and Diplomats. US Policymaking in Colombia. Stanford: Stanford University Press.

Teitel, R. (2003). Transitional Justice Genealogy. Harvard Human Rights Journal. $16,69-94$.

Torrejón, E. Posada, N., \& Castaño, F. (2015). Restitución de tierras. Experiencias de Mujeres en Antioquia, Colombia. Work in Progress. Presentation at the National Anthropology Congress, Santa Marta (Colombia), June 2-5.

Tsing, A.(2005). Friction. An Ethnography of Global Connection. Princeton: Princeton University Press.

Unidad de Restitución de Tierras (URT) (2013). Respuesta a Derecho de Petición. Septiembre 25. Colombia: UAEGRTD. Retreived from https://www.restituciondetierras.gov.co/ 
Unidad de Restitución de Tierras (URT) (2014). Informe de Gestión 2013. Colombia: UAEGRTD. Retrieved from https://www.restituciondetierras.gov.co/ informes-de-gestion

Vargas, C., \& Villarreal, N. (2014). La mujer rural en Colombia: un análisis del Programa de Mujer Rural del Ministerio de Agricultura y Desarrollo Rural. Bogotá: OXFAM.

Waardt, M. de (2014). In the name of the victims? Victim-survivor Associations Negotiating for Recognition in Post-Conflict Peru. Amsterdam: M. de Waardt.

Walker, M. U. (2009). Gender and Violence in Focus: A Background for Gender Justice in Reparations. In Rubio, R. (Ed.) The Gender of Reparations. Unsettling Sexual Hierarchies While Redressing Human Rights Violations (pp. 18-62). Cambridge: Cambridge University Press. 